Check for updates

Cite this: RSC Adv., 2020, 10, 21974

Received 11th May 2020

Accepted 1st June 2020

DOI: $10.1039 / \mathrm{d} 0 \mathrm{ra0} 4213 \mathrm{~g}$

rsc.li/rsc-advances

\section{Arenium cation or radical cation? An insight into the cyclodehydrogenation reaction of 2- substituted binaphthyls mediated by Lewis acids $\uparrow$}

\author{
Patricia Camargo Solórzano, María T. Baumgartner, (D) Marcelo Puiatti (D)* \\ and Liliana B. Jimenez (D)*
}

Perylene and its derivatives are some of the most interesting chromophores in the field of molecular design. One of the most employed methodologies for their synthesis is the cyclodehydrogenation of binaphthyls mediated by Lewis acids. In this article, we investigated the cyclodehydrogenation reaction of 2substituted binaphthyls to afford the bay-substituted perylene. By using $\mathrm{AlCl}_{3}$ as a Lewis acid and high temperatures (the Scholl reaction), two new products bearing $\mathrm{NH}_{2}$ and $\mathrm{N}\left(\mathrm{CH}_{3}\right)_{2}$ groups at position 2 of the perylene ring were synthesized. Under these conditions, we were also able to obtain terrylene from ternaphthalene in $38 \%$ yield after two cyclodehydrogenation reactions in a single step. The attempts to promote the formation of a radical cation (necessary intermediary for the oxidative aromatic coupling mechanism) by using $\mathrm{FeCl}_{3}$ or a strong oxidant like 2,3-dichloro-5,6-dicyano-1,4-benzoquinone (DDQ) did not yield the expected products. DFT calculations suggested that the lack of reaction for oxidative aromatic coupling is caused by the difference between the oxidation potentials of the donor/acceptor couple. In the case of the Scholl reaction, the regiochemistry involved in the formation of the $\sigma$ complex together with the activation energy of the $\mathrm{C}-\mathrm{C}$ coupling reaction helped to explain the differences in the reactivity of the different substrates studied.

\section{Introduction}

In the last decades, there has been special interest in the design of specific chromophoric structures due to their possible application in molecular devices such as light-collecting antennas and organic light emitting diodes (OLEDs), among other applications. ${ }^{1}$ Among these structures, perylene and its derivatives are particularly interesting, since they exhibit excellent electronic and optical properties. ${ }^{2}$ Perylene shows characteristic fluorescence with high quantum yield, which varies depending on both the nature of the substituents attached to the polycycle and their positions (e.g. the axial or equatorial regions). ${ }^{3}$ Recent applications of perylene derivatives (mostly perylene diimides, PDIs), ${ }^{4}$ include organic field effect transistors, ${ }^{5}$ organic photovoltaic cells, ${ }^{6}$ optical switches ${ }^{7}$ and molecular wires. ${ }^{8}$

Because of the importance of perylene and its derivatives, different strategies have been developed for their synthesis (Scheme 1, I-V). Among these routes are intramolecular

INFIQC, Departamento de Química Orgánica, Facultad de Ciencias Químicas, Universidad Nacional de Córdoba, Ciudad Universitaria, X5000HUA, Córdoba, Argentina. E-mail: mpuiatti@fcq.unc.edu.ar; ljimenez@fcq.unc.edu.ar; Tel: +54-351-5353867 int. 53330

$\uparrow$ Electronic supplementary information (ESI) available: Spectroscopic data and computational information. See DOI: $10.1039 /$ d0ra04213g condensation of quinone derivatives (I), ${ }^{9}$ base-induced dimerization of benzoisoquinoline-diones (II),$^{10}$ the Ullmann reaction (III) ${ }^{11}$ decarboxylation of the perylene-3,4,9,10-tetracarboxylic dianhydride mediated by basic conditions (IV), ${ }^{12}$ and the cyclodehydrogenation of the binaphthalene (V). ${ }^{13}$ In general, the yields of these reactions are good to low. Perhaps, the best option to obtain large quantities of perylene is route IV, but it usually requires high temperatures (more than $350{ }^{\circ} \mathrm{C}$ ). On the other hand, route $\mathrm{V}$ is an attractive option, since it can take place through up to three different mechanisms depending on the reactants and the experimental conditions used. For example, Rickhaus et al. ${ }^{\mathbf{1 3 d}}$ were able to obtain quantitative yields of perylene by using an excess of electrons (route V), however no bay-substituted perylene was reported following this last one. Despite these recent advances, the synthetic procedures to generate perylene are currently limited. Furthermore, only routes I and II can yield substituted perylenes; perisubstituted (axial region) by route II and ortho- and baysubstituted by route I.

Although the Lewis acid-mediated cyclodehydrogenation (another way by which route V can occur) is one of the oldest methodologies used to obtain polycyclic aromatic hydrocarbons ${ }^{\mathbf{1 4}}$ i.e. perylene, $^{\mathbf{1 3 b}, \mathbf{1 5}}$ terrylene, ${ }^{\mathbf{1 6}}$ and dibenzotetraphenylperiflanthene, ${ }^{17}$ the operating mechanism presents some ambiguities. In front of this discussion, Gryko et al. ${ }^{18}$ proposed the distinction between two possible mechanisms 


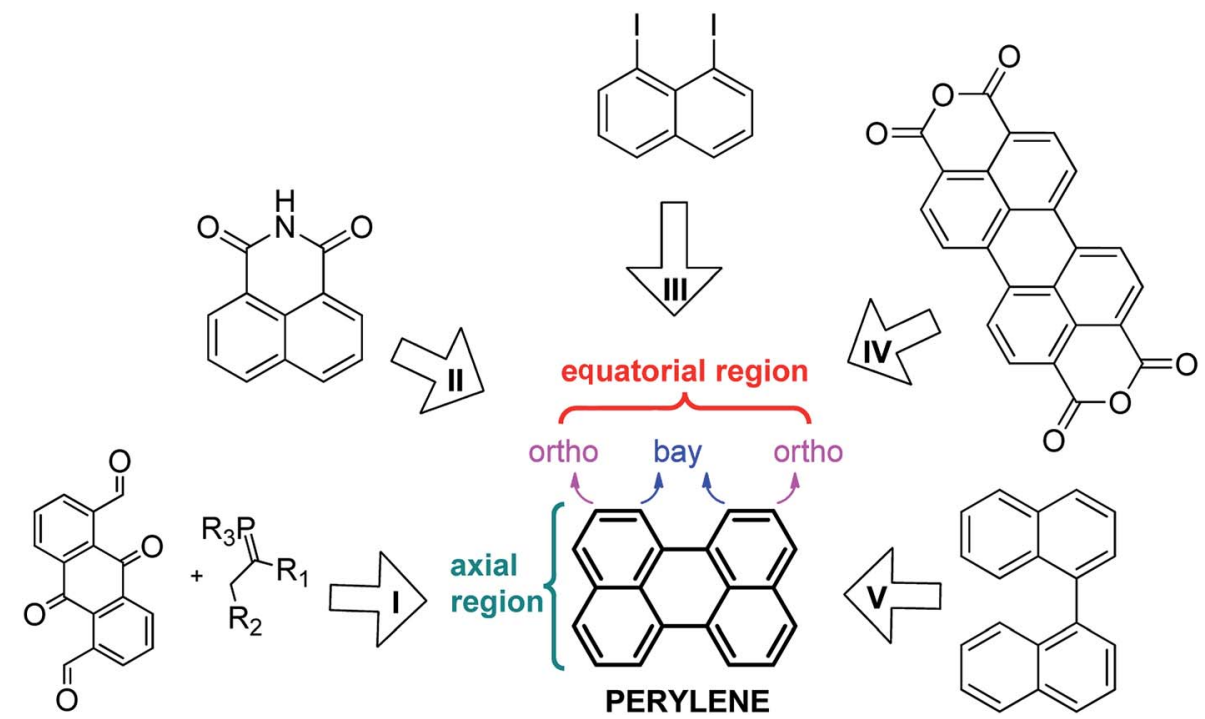

Scheme 1 Retrosynthesis of perylene. Route: (I) intramolecular condensation of quinone derivatives; (II) dimerization of benzoisoquinolinediones in basic media; (III) Ullmann reaction; (IV) decarboxylation of the perylene tetracarboxylic dianhydride mediated by basic conditions and high temperatures and $(\mathrm{V})$ cyclodehydrogenation of the binaphthalene.

through which polycyclic aromatic products can be generated. One of the postulated mechanisms is known as the Scholl reaction, that proceeds through the formation of an electrophilic complex or $\sigma$-complex (shown as $\mathrm{H}^{+}$for simplicity in Scheme 2, but it could also be a $\sigma$-complex formed with a Lewis acid)..$^{18}$ Usually, methodologies related to this mechanism involve the use of strong Lewis acids such as $\mathrm{AlCl}_{3}$ dissolved in chlorobenzene, ${ }^{19}$ complexes of fused salts such as $\mathrm{AlCl}_{3} / \mathrm{NaCl}^{20}$ or $\mathrm{AlCl}_{3} / \mathrm{SO}_{2},{ }^{21}$ among others. ${ }^{15}$

In contrast, the other proposed mechanism for the reactions mediated by Lewis acids is the oxidative aromatic coupling. This mechanism involves the formation of a radical cation, followed by an intramolecular cyclization and rearomatization to give the polycyclic product (Scheme 2, left side). ${ }^{18}$ The experimental conditions to carry out this reaction involve the use of either Lewis acids such as $\mathrm{FeCl}_{3}$ (ref. 22) or strong oxidants like 2,3dichloro-5,6-dicyano-1,4-benzoquinone (DDQ). ${ }^{23}$

The ambiguity of these reactions relies on the fact that sometimes there is no clear evidence of the operating mechanism, and they are said to occur through the Scholl mechanism without any discrimination. One of the reasons contributing to this confusion is the fact that most of the Lewis acids used in

\section{Oxidative Aromatic Coupling Scholl Reaction}<smiles>[C+](=Cc1cccc2ccccc12)=Cc1cccc2ccccc12</smiles><smiles></smiles>

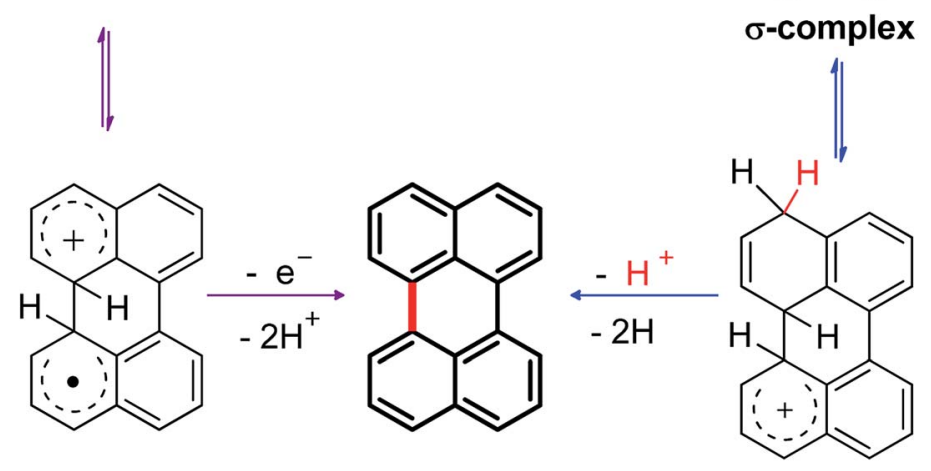

Scheme 2 General mechanisms proposed for the cyclodehydrogenation reaction in oxidizing media (mediated by Lewis acids). 


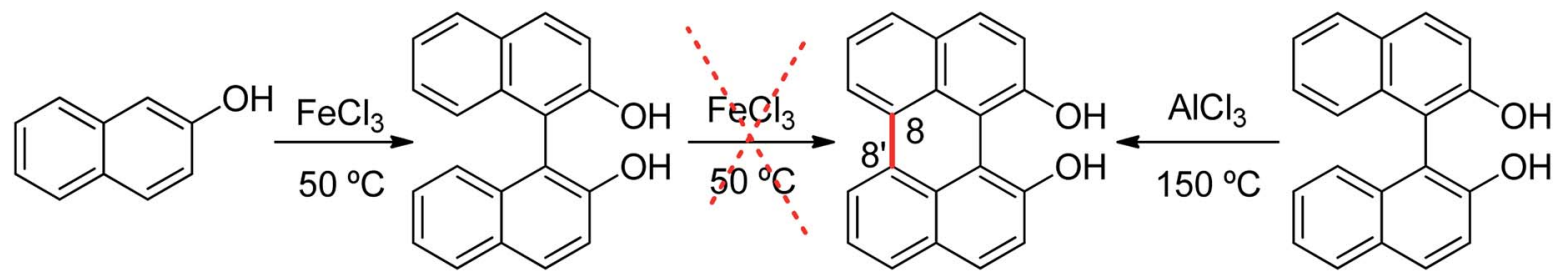

Scheme 3 Formation of perylene-1,12-diol.

the Scholl reaction are also mild oxidants commonly employed in oxidative aromatic coupling reactions. ${ }^{22,24}$ In this regard, in some cases DFT calculations have been used to help to solve this issue. ${ }^{25}$

A prominent example in which it is possible to distinguish between oxidative aromatic coupling and Scholl mechanism is the reaction of 2-naphthol in the presence of an oxidant such as $\mathrm{FeCl}_{3}$ at $50{ }^{\circ} \mathrm{C}^{26}$ Under these conditions, 2,2'-dihydroxy-1,1'binaphthalene is formed by an oxidative aromatic coupling reaction (Scheme 3). However, it is not possible to obtain the perylene-1,12-diol compound, even when additional portions of $\mathrm{FeCl}_{3}$ were added to the system. ${ }^{18}$ In contrast, the $\mathrm{C}-\mathrm{C}$ bond formation (C-8 with $\left.\mathrm{C}-8^{\prime}\right)$ to give the perylene-1,12-diol can be achieved by heating $2,2^{\prime}$-dihydroxy-1,1'-binaphthalene with $\mathrm{AlCl}_{3}$ at $150{ }^{\circ} \mathrm{C}$ (Scholl conditions). ${ }^{27}$

A similar behavior was also observed with naphthyl isoquinolines. ${ }^{13 e}$ The compound 1-(naphthalen-1-yl)-isoquinoline reacts with a melted mixture of $\mathrm{AlCl}_{3} / \mathrm{NaCl}$ at $160{ }^{\circ} \mathrm{C}$ to provide 1-azaperylene in $68 \%$ yield, but cyclization does not occur when 8-(naphthalen-1-yl)-isoquinoline is exposed to the same conditions. Moreover, neither of the two isomeric naphthyl isoquinoline substrates react in the presence of $\mathrm{FeCl}_{3}$ at $25{ }^{\circ} \mathrm{C}$ and $80{ }^{\circ} \mathrm{C} .{ }^{18}$

Considering the aforementioned antecedents, 2-substituted binaphthalenes ${ }^{28}$ were synthesized and used as substrates for the preparation of equatorially functionalized perylenes. The study of the reactivity of these binaphthyl compounds can generate important contributions to the understanding of mechanisms associated with cyclodehydrogenation reactions mediated by Lewis acids. A comparison between the arenium cation ( $\sigma$-complex or Scholl) mechanism and the cyclodehydrogenation initiated by radical cations (oxidative aromatic coupling) is presented for all synthesized compounds. The discussion is complemented with DFT computational studies. Furthermore, the peculiar formation of two $\mathrm{C}-\mathrm{C}$ bonds in a single reaction step is presented in the synthesis of terrylene (tribenzo[de,kl,rst $]$ pentaphene) from $1,1^{\prime}: 4^{\prime}, 1^{\prime \prime}$-ternaphthalene.

\section{Results and discussion}

\section{Scholl and oxidative aromatic coupling experimental reactions}

In an initial approach, the intramolecular cyclization of the substrates [1,1'-binaphthalen]-2-amine (1), $N, N$-dimethyl-[1,1'binaphthalen]-2-amine (2) and 2-methoxy-1,1'-binaphthalene (3) was experimentally evaluated following both reaction conditions, Scholl (Table 1) and oxidative aromatic coupling.

The substrates were allowed to react at $170{ }^{\circ} \mathrm{C}$ within the salt mixture of $\mathrm{AlCl}_{3} / \mathrm{NaCl}$ during different reaction times (Table 1, entries 1-4). Compounds 1 and 2 afforded the cyclized products

Table 1 Results of the Scholl reaction for the substrates 1-3

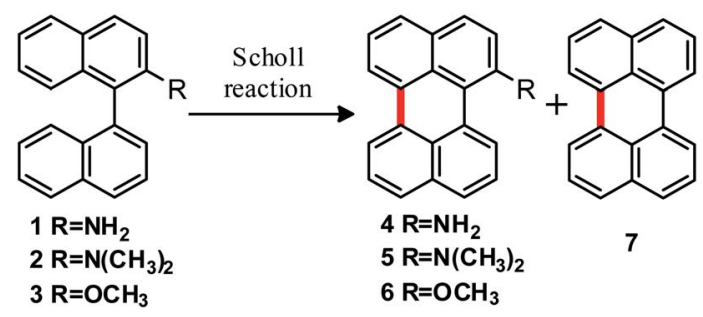

\begin{tabular}{lllll}
\hline Entry & Scholl reaction $^{a}$ & Products $^{b}(\%)$ & Remaining substrate $^{c}(\%)$ \\
\hline 1 & $\mathrm{AlCl}_{3} / \mathrm{NaCl}, 170{ }^{\circ} \mathrm{C}, 15 \mathrm{~min}$ & $\mathbf{4}(27)^{c}$ & $\mathbf{7 ( 2 1 )}$ & $\mathbf{1}(12)$ \\
2 & $\mathrm{AlCl}_{3} / \mathrm{NaCl}, 170{ }^{\circ} \mathrm{C}, 30 \mathrm{~min}$ & $\mathbf{4}(12)^{c}$ & $\mathbf{7 ( 3 9 )}$ & $\mathbf{1}(<5)$ \\
3 & $\mathrm{AlCl}_{3} / \mathrm{NaCl}, 170{ }^{\circ} \mathrm{C}, 10 \mathrm{~min}$ & $\mathbf{5}(50)$ & $\mathbf{7}(12)$ & $\mathbf{2}(<5)$ \\
4 & $\mathrm{AlCl}_{3} / \mathrm{NaCl}, 170{ }^{\circ} \mathrm{C}, 20 \mathrm{~min}$ & $\mathbf{5}(40)$ & $\mathbf{2}(-)$ & $\mathbf{2}(<5)$ \\
$5^{d}$ & $\mathrm{AlCl}_{3} / \mathrm{C}_{6} \mathrm{H}_{5} \mathrm{Cl}, 80^{\circ} \mathrm{C}, 6 \mathrm{~h}$ & $\mathbf{6}(-)$ &
\end{tabular}

${ }^{a} \mathrm{AlCl}_{3} / \mathrm{NaCl}$ (5 : 1 eq.), substrate (0.2 eq., $\left.0.1 \mathrm{mmol}\right) .{ }^{b}$ Isolated yields. ${ }^{c}$ Quantified by CG-FID using the internal standard method. ${ }^{d}$ Substrate (0.2 $\mathrm{mmol}), \mathrm{AlCl}_{3}(1.8 \mathrm{mmol}), \mathrm{C}_{6} \mathrm{H}_{5} \mathrm{Cl}(10 \mathrm{~mL})$. 
4 and 5, respectively. To the best of our knowledge, this work describes a synthetic protocol for obtaining products $\mathbf{4}$ and $\mathbf{5}$ for the first time, since although compound $\mathbf{4}$ is mentioned in some patents, no data on the synthetic procedure or the reaction performance are known. Compound 4 decomposes under air and during purification in column chromatography (on silica gel). On the other hand, compound 5 has never been reported in literature and showed high fluorescence $\left(\varepsilon_{5}(455 \mathrm{~nm})\right.$ $=6869 \mathrm{M}^{-1} \mathrm{~cm}^{-1} ; \Phi_{\mathrm{f}}(5)=0.92$ in dichloromethane). ${ }^{30}$ In all cases, perylene (7) was found to be the main side product, in addition to substrate that did not react.

It is known that $1,1^{\prime}$-binaphthalene isomerizes to $1,2^{\prime}$ binaphthalene under acid-catalyzed conditions, as a consequence of the formation of an ipso-arenium ion. This process competes with the cyclodehydrogenation to form perylene; ${ }^{31}$ for example, formation of benzo[j]fluoranthene and related compounds is observed when isomerization occurs. ${ }^{31 a}$ In our case, the C-2' position is blocked by the amino substituent, precluding isomerization process. In consequence, no isomerization-derived products were observed in the assayed reactions.

On the other hand, we assume that the formation of 7 could come from deamination of the products 4 or 5 due to the strongly acidic and high temperature conditions. This hypothesis is supported by the fact that an increase of reaction time leads to an increase in perylene (7) yield together with a decrease of the amino-perylene product yield (entries 2 and 4, Table 1). Although there exist several possible mechanisms for deamination of different amino compounds, ${ }^{32}$ at this stage we cannot unequivocally choose the mechanism involved in our case.

Substrate 3 has a melting point of $109-110{ }^{\circ} \mathrm{C}$ and decomposes at $125-127{ }^{\circ} \mathrm{C}^{33}$ For this reason, milder Scholl reaction conditions were assayed with this substrate. ${ }^{19}$ A solution of $\mathrm{AlCl}_{3}$ in dry chlorobenzene at $80{ }^{\circ} \mathrm{C}$ was used to promote the reaction (entry 5, Table 1); however, no intramolecular cyclization product was observed and 2-methoxynaphthalene was obtained as major product, due to the $\mathrm{C} 1-\mathrm{C} 1^{\prime}$ bond cleavage of the substrate. Some minor products from coupling between

Table 2 Most probable positions for the protonation to form the $\sigma$-complex for $1 a, 3,8 a$ and $9 a$

Substrates

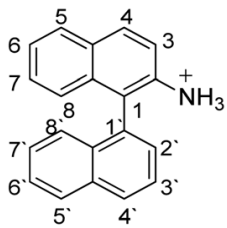

$1 \mathrm{a}$

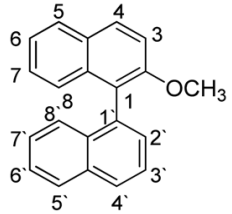

3
Reference compounds

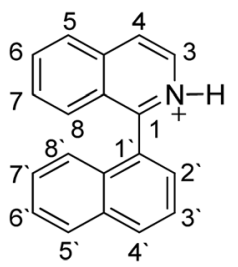

$8 a$<smiles>[C+]1=CC=Cc2ccccc2C=1</smiles>

9a
$1(98 \%)$
$6(1 \%)$ $5^{\prime}(31 \%)$

$8^{\prime}(66 \%)$ $5^{\prime}(46 \%)$

$8^{\prime}(39 \%)$ 
<smiles>[R]c1ccc2ccccc2c1-c1cccc2ccccc12</smiles>

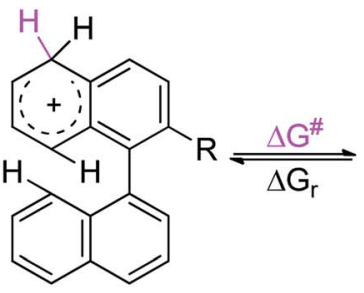

$\sigma$-complex

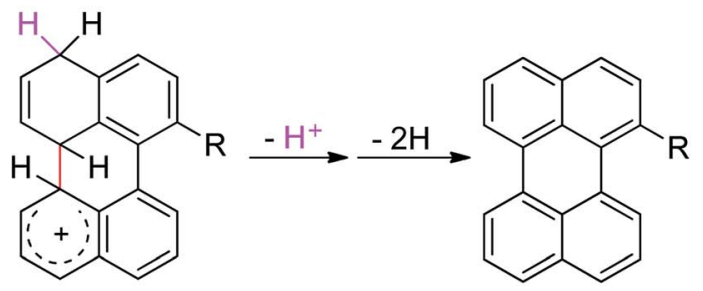

intermediary

Scheme 4 Scholl mechanism proposed for the formation of 2-R-perylene.

\section{Scholl reaction}

Firstly, we address the following question, is it possible that under Scholl reaction conditions - the substrates 1, 2 and 3 may react via the formation of the $\sigma$-complex? Two reference compounds were now included, 1-(naphthalen-1-yl) isoquinoline (8) and 8-(naphthalen-1-yl)isoquinoline (9). ${ }^{18}$ From these compounds, 8 reacted by the Scholl experimental condition whereas $\mathbf{9}$ could not form the cyclized product; they should work as positive and negative tests, respectively.
Since the reactions were carried out in acidic media, the formation of the arenium cation was the first evaluated process. To study the regiochemistry of the protonation of each substrate, the relative energy difference required to form the $\sigma$ complex at different positions of the aromatic rings was calculated. A Boltzmann population analysis for the formation of the $\sigma$-complex was estimated at $170{ }^{\circ} \mathrm{C}$ (see $\mathrm{ESI} \dagger$ ), the most favored positions are shown in Table $2 .^{29}$ It should be noted that the amino group must be protonated due to the acidic media used

Table 3 Relative free energy of formation of $\sigma$ complex $\left(\Delta \Delta G_{\sigma}\right)$, free energies of activation $\left(\Delta G^{\#}\right)$ and reaction $\left(\Delta G_{r}\right)$ for the intramolecular ring closure by Scholl reaction mechanism ${ }^{a}$

\begin{tabular}{|c|c|c|c|c|c|}
\hline & $\sigma$-Complex & $\Delta \Delta G_{\mathrm{r}}\left(\mathrm{kcal} \mathrm{mol}^{-1}\right)$ & $\Delta G_{\mathrm{r}}\left(\mathrm{kcal} \mathrm{mol}^{-1}\right)$ & $\begin{array}{l}\Delta G^{\#}(\mathrm{kcal} \\
\left.\mathrm{mol}^{-1}\right)\end{array}$ & Intermediary \\
\hline $1 \sigma$ & & 2.0 & 19.1 & 24.5 & \\
\hline $2 \sigma$ & & 6.7 & 18.3 & 23.1 & \\
\hline $8 \sigma$ & & 0.0 & 23.2 & 26.1 & \\
\hline $9 \sigma$ & & 3.0 & 39.9 & 40.3 & \\
\hline
\end{tabular}

\footnotetext{
${ }^{a}$ All the energies were calculated at B3PW91/6-31+G* using $N$-methylformamide as solvent, IEFPCM model. The energies correspond to the sum of
} electronic energy, solvation, and thermal free energies. 
in the reactions. In this way, the cation of the substrate 1 (1a) was used, ${ }^{37}$ as well as the isoquinolinium cations (8a and 9a) which come from the protonation of the reference compounds 8 and 9.

The protonation at positions $5^{\prime}$ and $8^{\prime}$ was found to be the energetically favored for 1a, 8a and 9a. When the $\sigma$-complex is generated on position $5^{\prime}$, the redistribution of the charge within the ring leads to an intramolecular electrophilic attack, which would generate a new $\mathrm{C}-\mathrm{C}$ bond between $\mathrm{C}-8$ and $\mathrm{C}-\mathrm{8}^{\prime}$ (Scheme 2 ). On the other hand, if the $\sigma$-complex is generated in position $8^{\prime}$, the cyclization does not take place because a C-sp ${ }^{3}$ is formed at this position. For compound 3 the position 1 is the favored one for the protonation; however, this position does not favor the cyclization reaction.

To gain a deeper understanding of these reactions, the calculations of two different stages of the proposed Scholl mechanism (Scheme 4) were carried out. First, the free energy values obtained for the formation of the $\sigma$-complex $\left(\Delta \Delta G_{\sigma}\right)$ were computed, using the reaction of $\mathbf{8 a}$ as reference. ${ }^{38}$ Secondly, the activation and reaction free energies $\left(\Delta G^{\#}\right.$ and $\Delta G_{\mathrm{r}}$ respectively) involved in the intramolecular cyclization were evaluated; the results are presented in Table 3 . The last stage of the total reaction is an oxidation with re-aromatization of the formed cycle, which should provide an important driving force.

The $\Delta \Delta G_{\sigma}$ values for the formation of complexes $1 \sigma$ and $2 \sigma$ to promote the Scholl reaction compared to that of $\mathbf{8 \sigma}$, that is used as a reference of a compound that effectively reacts by the Scholl mechanism, indicate that it might be a possible step, even though it would entail a higher energy cost $\left(2.0 \mathrm{kcal} \mathrm{mol}^{-1}\right.$ for $1 \sigma$ and $6.7 \mathrm{kcal} \mathrm{mol}^{-1}$ for $2 \sigma$ ). According to the energy of formation of the $9 \sigma$ complex $\left(\sim 3.0 \mathrm{kcal} \mathrm{mol}^{-1}\right.$ higher than that of $8 \sigma$ ), compound 9 could also lead to the cyclization product. However, this product was not found when the reactions were carried out, hence the discrimination could take place after that step.

When the $\Delta G^{\#}$ energies for the intramolecular coupling were studied, it was found that the $\Delta G^{\#}$ for arenium cations $1 \sigma$ and $\mathbf{2} \sigma$ were lower than $\mathbf{8} \sigma$. Particularly, the $\mathbf{9} \boldsymbol{\sigma}$ complex presented values of $\Delta G^{\#}$ and $\Delta G_{\mathrm{r}}$ for ring closure higher than the other compounds. The difference exceeds $15 \mathrm{kcal} \mathrm{mol}^{-1}$, which would indicate that, in this case, the $\mathrm{C}-\mathrm{C}$ coupling stage does discriminate between substrates that cyclize and those that do not generate intramolecular cyclization by this mechanism. This difference in the $\Delta G^{\#}$ and $\Delta G_{\mathrm{r}}$, compared with the values for $\mathbf{8 \sigma}$, are ascribed to the differences in the electronic distributions of $1 \sigma, 8 \sigma$ and $9 \sigma$, as presented in Fig. 1. For $1 \sigma$ and $8 \sigma$ the charges at position 5 and $8^{\prime}$ are negative and positive respectively, whereas in the case of $\mathbf{9 \sigma}$ the negative charge is closer to zero due to the protonated nitrogen adjacent to the $8^{\prime}$ position. The electrostatic potential help to explain how the charge is distributed after the formation of the $\sigma$ complex, and which positions are nucleophilic and/or electrophilic, favoring (or not) the cyclization by an electrophilic attack.

As it was mentioned before, the cyclized product 6 derived from compound 3 by Scholl reaction was not observed (entry 5 , Table 1). According to the analysis of the electrostatic potential of $3 \sigma$ (with $\mathrm{H}^{+}$in position 1 ), $\mathrm{C}-5^{\prime}$ and $\mathrm{C}-8$ do not possess the expected charges that favor the coupling (see ESI $\dagger$ ). In addition, the free energy for the intramolecular ring closure of $3 \sigma$ is higher than the one found for compound $9 \boldsymbol{\sigma}$ which was used as reference of a nonreactive compound. ${ }^{39}$

\section{Oxidative aromatic coupling}

Finally, the reactivity of substrates 1-3 within oxidative aromatic coupling mechanism was also examined with
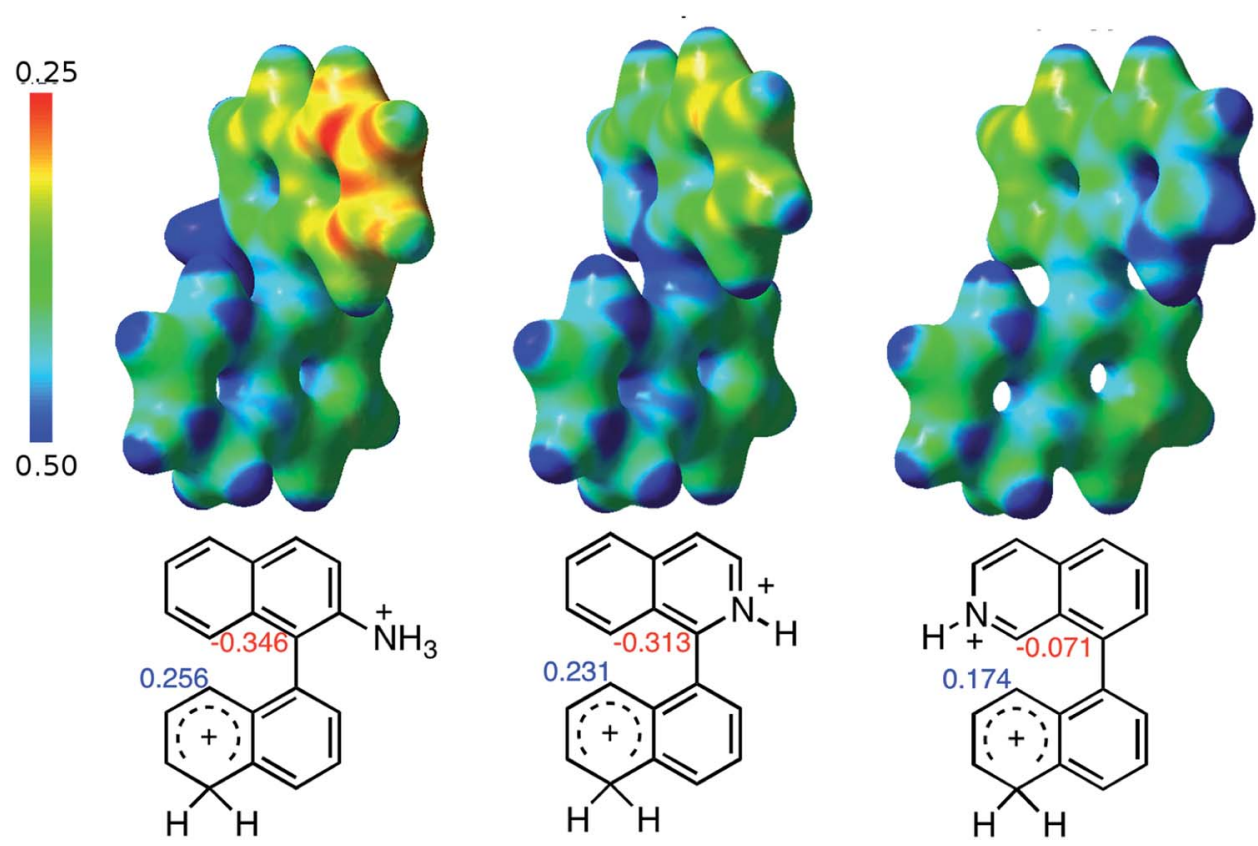

Fig. 1 Representation of the electrostatic potential of the $\sigma$-complex of $1 \sigma, 8 \sigma$ and $9 \sigma$. In the small figure are represented the point charges that fit the electrostatic potential, according to the Merz-Singh-Kollman ${ }^{40}$ scheme, for C-5 and C- $8^{\prime}$. 

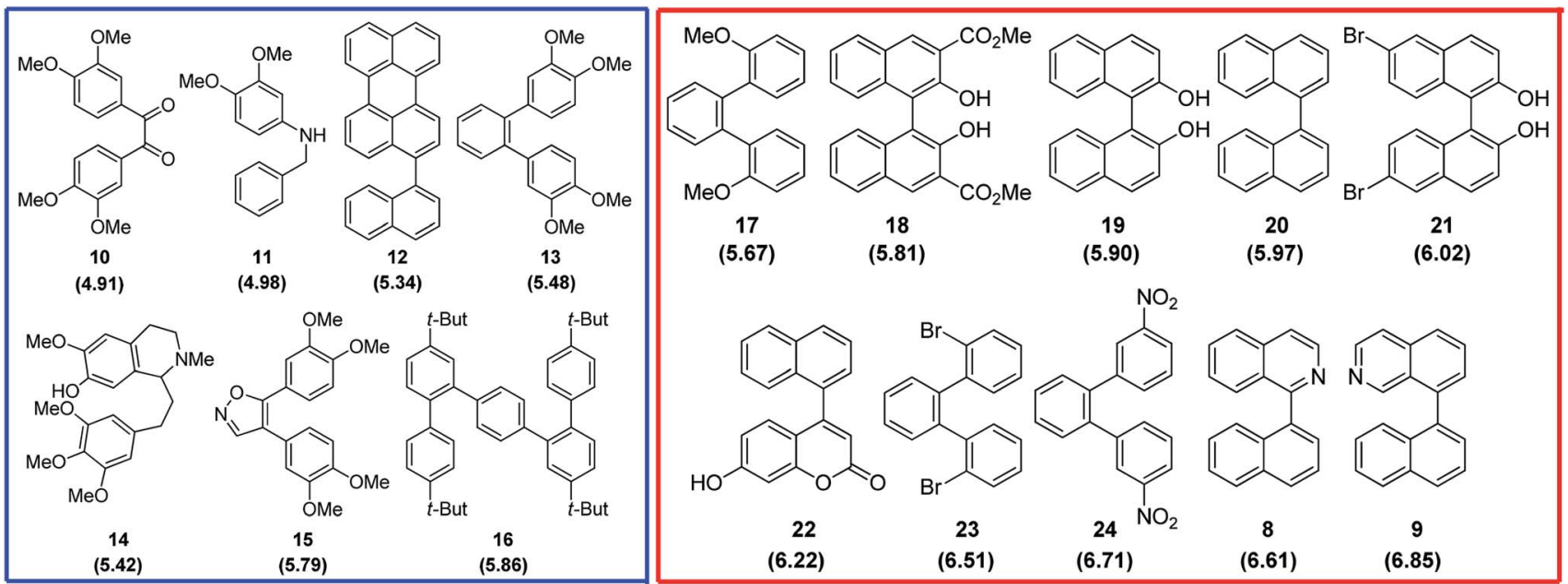

Fig. 2 Structure of the reference compounds for oxidative aromatic coupling mechanism. Blue square: Group 1 (reactive); red square: Group 2 (non reactive). Calculated oxidation potential (eV) in parenthesis. ${ }^{42}$

computational studies. The feasibility of initiating the reaction through this mechanistic pathway (Scheme 2) was first evaluated by comparing the computed oxidation potentials. ${ }^{41}$ They were calculated for both, substrates and a group of reference molecules, the results are represented in Fig. 2. The set of reference compounds was split into two groups (Fig. 2): Group 1 (blue box) includes those compounds reported as useful for generating intramolecular cyclization mediated by an intermediary radical cation (using different oxidant agents, i. e. $\mathrm{FeCl}_{3}$, $\mathrm{DDQ} / \mathrm{H}^{+}, \mathrm{MoCl}_{5}$, etc.); Group 2 (red box) includes those compounds that do not produce cyclization under oxidative aromatic coupling experimental conditions. ${ }^{42}$

As expected, the results suggest that compounds from Group 1 have lower oxidation potentials. Meanwhile, the compounds from Group 2 have higher oxidation potentials (Fig. 3).

The oxidation potential values found for substrates 1-3 are in the region of the compounds that would hardly generate the necessary radical cation which initiates the reaction via the oxidative aromatic coupling mechanism. This could explain the lack of reactivity of these substrates experimentally observed.

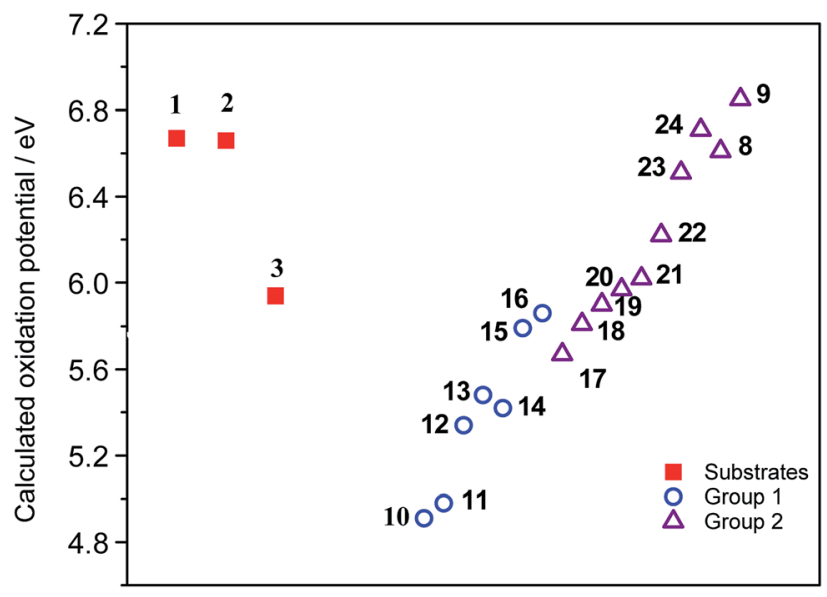

Fig. 3 Calculated oxidation potential of the studied compounds.
These results are in concordance with the previously proposed oxidation potential limit by Rathore et al. when $\mathrm{DDQ} / \mathrm{H}^{+}$is used as oxidant agent for cyclization of electron-rich molecules. ${ }^{18,23} \mathrm{It}$ should be noted that this estimation of the oxidation potential, could help to predict the reactivity of new compounds toward these oxidative aromatic coupling reactions.

\section{Cyclization of $1,1^{\prime}: 4^{\prime}, 1^{\prime \prime}$-ternaphthalene}

In order to explore the scope of these reactions, we propose the synthesis of terrylene from $1,1^{\prime}: 4^{\prime}, 1^{\prime \prime}$-ternaphthalene (25), Scheme 5. In this reaction there is also another challenge, two new $\mathrm{C}-\mathrm{C}$ bonds have to be formed to yield the expected product. Reaction of $1,1^{\prime}: 4^{\prime}, 1^{\prime \prime}$-ternaphthalene with a mixture of $\mathrm{AlCl}_{3} /$ $\mathrm{NaCl}(5: 1)$ was carried out during $20 \mathrm{~min}$ at $170{ }^{\circ} \mathrm{C}$, the corresponding double cycled product terrylene (26) was obtained in $38 \%$ isolated yield. It is important to stand out that two new $\mathrm{C}-\mathrm{C}$ bonds were generated within the same procedure. Perylene $7(23 \%)$ was also obtained as a side product and substrate 25 (20\%) was recovered.

The molecular modeling studies of compound 25 indicated that the positions $4(64 \%)$ and $5(11 \%)$ are the ones that protonate mostly, but the $\Delta G^{\#}$ and $\Delta G_{\mathrm{r}}$ for the coupling are markedly favored for the $\sigma$-complex generated in position 5 (see ESI $\dagger$ ). The electrostatic potential of both intermediary $\sigma$ complexes are really different and help to explain this energetic difference observed for the coupling at these positions. Finally, starting form the $\sigma$-complex protonated at position 5 , the energies involved in two consecutive $\mathrm{C}-\mathrm{C}$ couplings of $\mathbf{2 5 \sigma}$, are slightly lower than the energy values found for the other binaphthyl derivatives previously studied $(\mathbf{1}, \mathbf{2}$, and $\mathbf{8})$.

As it was found for substrates $\mathbf{1 - 3}$, when substrate 25 was also exposed to oxidative aromatic coupling conditions using DDQ as the oxidant agent, the formation of the product $\mathbf{2 6}$ was not detected. Again, $\mathbf{2 5}$ was also treated with a solution of $\mathrm{FeCl}_{3}$ in $\mathrm{CH}_{3} \mathrm{NO}_{2}$. The reaction led to the formation of an inseparable mixture of products that could not be characterized. Moreover, none of them showed the typical fluorescence or UV-absorption 


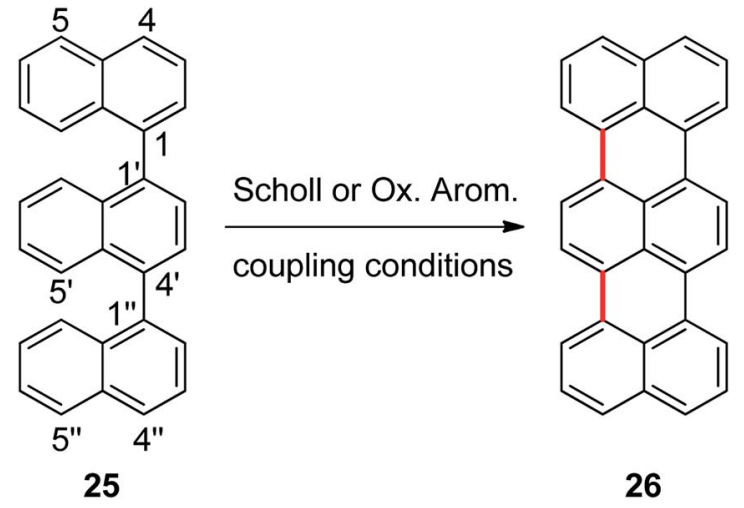

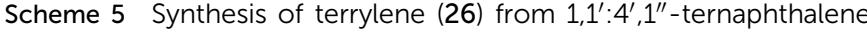
(25) by Scholl or oxidative aromatic coupling experimental conditions.

profile of the terrylene. ${ }^{16 a}$ The computed oxidation potential found for 25 was $6.15 \mathrm{eV}$. Considering Fig. 2, the compound 25 is classified within the group of compounds that do not react by the methodology of oxidative aromatic coupling.

In brief, the results obtained by computational modeling help to explain the observed reactivity of the tested ternaphthyl compound, under both reaction conditions. Moreover, it was possible to obtain terrylene, going through two consecutive C-C coupling reactions, in a simple experimental step with Scholl conditions.

\section{Conclusions}

To summarize, three compounds derived from perylene, two of them functionalized in the equatorial region, were synthesized by a cyclodehydrogenation reaction mediated by Lewis acids, from their respective 2-substituted binaphthalene compounds through a mechanistic pathway that involves the formation of the $\sigma$-complex. Regarding the studies performed by computational methods, the regiochemistry for the formation of the $\sigma$ complex should be studied. An analysis of the electrostatic potential isosurface of the $\sigma$-complexes was very useful to predict the outcome of the cyclization reaction. According to these analyses, within this experimental condition $\left(\mathrm{AlCl}_{3} / \mathrm{NaCl}\right.$, $170{ }^{\circ} \mathrm{C}$ ), substrates 1,2 and 25 can generate the $\sigma$-complex to initiate the reaction and consequently, produce an intramolecular cyclization. For substrate $\mathbf{3}$, the results suggest that the formation of the initial $\sigma$-complex is possible on position 1 , but the ring closure from the $\sigma$-complex is not energetically favored, consequently the product 6 was not observed.

On the other hand, the formation of the 2-substituted perylene products by cyclodehydrogenation reactions via oxidative aromatic coupling $\left(\mathrm{FeCl}_{3}\right.$ or DDQ as oxidants), e.g. radical cations as intermediates, was not detected. The studies carried out with DTF methods support that substrates 1, 2, 3, and 25 could not be experimentally oxidized and therefore, could not generate the intermediary radical cation, which is necessary to initiate the reaction and produce the cycled perylene derivative. In summary, we introduce an experimental system where it can be raised the difference between both mechanisms mediated by
Lewis acids, and again, molecular modeling is a powerful tool which, on this occasion, helped us to deeply understand the key points to be considered for achieving a successful reaction.

As Gryko proposed, ${ }^{18}$ there is a clear mechanistic difference when any substrate is exposed to Lewis acids to generate a dehydrogenative aromatic coupling product by Scholl reaction or by oxidative aromatic coupling. According to the analysis of both reactions by using molecular modeling methods, it could be possible to explain differences in reactivity and to predict the outcome of a reaction with a new substrate.

\section{Experimental section}

\section{General methods}

Sodium chloride ( $\mathrm{NaCl})$, nitromethane $\left(\mathrm{CH}_{3} \mathrm{NO}_{2}\right)$, 2,3-dichloro-5,6dicyano- $p$-benzoquinone (DDQ), and trifluoromethanesulfonic acid (TFMSA) were obtained from Sigma-Aldrich and used as received. Iron trichloride $\left(\mathrm{FeCl}_{3}\right)$ was obtained from Merck Millipore and used as received. Aluminum trichloride $\left(\mathrm{AlCl}_{3}\right)$ was obtained commercially and sublimated before used. Dichloromethane was obtained commercially, distilled, and stored under molecular sieves $(4 \AA)$. Gas chromatographic analysis was performed on a Varian GC with a flame ionization detector and equipped with a VF-5 ms, $30 \mathrm{~m} \times 0.25 \mathrm{~mm} \times 0.25 \mu \mathrm{m}$ column. Gas chromatographic/mass spectrometer analysis was carried out on a Shimadzu GC-MS QP 5050 spectrometer equipped with a VF-5 $\mathrm{ms}, 30 \mathrm{~m} \times 0.25 \mathrm{~mm} \times 0.25 \mu \mathrm{m}$ column. HRMS were recorded on a Bruker, MicroTOF Q II equipment, operated with an ESI source in (positive/negative) mode, using nitrogen as nebulizing and drying gas and sodium formate $10 \mathrm{mM}$ as an internal standard. HPLC analysis was carried out on a Waters 1525 Binary HPLC Pump connected to a Waters 2998 Photodiode Array Detector, and employing an Agilent Rx-Sil Analytical column $(4.6 \times 150 \mathrm{~mm}, 5$ $\mu \mathrm{m})$. Elemental analysis was determined on a Perkin Elmer 2400 Series II CHNS/O with a thermal conductivity detector (TCD). ${ }^{1} \mathrm{H}$ NMR and ${ }^{13} \mathrm{C}$ NMR were recorded on a $400 \mathrm{MHz}$ Bruker nuclear magnetic resonance spectrometer.

The substrates $1,{ }^{28 a, 28 c} 3,{ }^{43}$ and 25 (ref. 44) were synthesized and purified by previously published methods, their NMR spectra are shown in ESI. $\dagger$ The new compound $N, N$-dimethyl$\left[1,1^{\prime}\right.$-binaphthyl]-2-amine (2) was obtained by the methylation of amine 1 (see ESI $\dagger$ ).

General procedure for the cyclodehydrogenation by Scholl reaction. A mixture of dry sodium chloride (30 mg, 1 eq.) and aluminum chloride $(333 \mathrm{mg}, 5$ eq.) was heated and stirred at $170{ }^{\circ} \mathrm{C}$ under nitrogen atmosphere. Once this mixture is melted, the substrate $(0.2$ eq., $0.1 \mathrm{mmol})$ was added. In the reactions carried out with substrates $\mathbf{1}$ and 2, after the reaction finished (reaction times are indicated in Table 1), the mixture was cooled to room temperature and extracted with $\mathrm{CH}_{2} \mathrm{Cl}_{2}$ and $\mathrm{H}_{2} \mathrm{O}(3 \times$ $25 \mathrm{~mL}$ ). The organic layer was dried under $\mathrm{Na}_{2} \mathrm{SO}_{4}$, filtered, and evaporated under reduced pressure. The crudes were analyzed by GC and GC-MS. In the case of the reaction of substrate $\mathbf{2 5}$, after the end of the reaction time $(20 \mathrm{~min})$, the mixture was cooled at room temperature and quenched with diluted $(10 \%)$ $\mathrm{HCl}(5 \mathrm{~mL})$. The resulting precipitate was filtered under suction and rinsed with $\mathrm{H}_{2} \mathrm{O}$. 
When milder conditions were employed in the Scholl reaction, 2-methoxy-1,1'-binaphthalene (3) (0.2 mmol, 1 eq.) was dissolved in dry dichloromethane $(10 \mathrm{~mL})$. After stirring for 20 min under $\mathrm{N}_{2}$ atmosphere, anhydrous aluminum chloride (1.8 mmol, 9 eq.) was added. The solution was stirred at $80{ }^{\circ} \mathrm{C}$ for $6 \mathrm{~h}$. For the extraction process, $\mathrm{CH}_{2} \mathrm{Cl}_{2}$ and $\mathrm{H}_{2} \mathrm{O}(3 \times 20 \mathrm{~mL})$ were used.

General procedure for the oxidative cyclodehydrogenation with DDQ and methanesulfonic acid. A solution of the substrate (0.4 mmol, 1 eq.) in dry dichloromethane $(4 \mathrm{~mL})$ containing methanesulfonic acid $(10 \% \mathrm{v} / \mathrm{v}, 0.8 \mathrm{~mL})$ at $\sim 0{ }^{\circ} \mathrm{C}$ was exposed to DDQ ( $0.4 \mathrm{mmol}, 1$ eq. per $\mathrm{C}-\mathrm{C}$ bond formation). The reaction was stirred under a nitrogen atmosphere from $30 \mathrm{~min}$ to $5 \mathrm{~h}$, at room temperature. The progress of the reaction was monitored by TLC. The reaction was quenched with a saturated aqueous solution of $\mathrm{NaHCO}_{3}(20 \mathrm{~mL})$. The dichloromethane layer was separated, washed with water and brine solution, dried over anhydrous $\mathrm{NaSO}_{4}$, and filtered.

General procedure for the oxidative cyclodehydrogenation using $\mathbf{F e C l}_{3}$. A solution of anhydrous iron(III) chloride (3.2 $\mathrm{mmol})$ in dry nitromethane $(3.2 \mathrm{~mL})$ was injected to a solution of the substrate $(0.4 \mathrm{mmol})$ in dry dichloromethane $(30 \mathrm{~mL})$ through a syringe. The solution was stirred at room temperature for $24 \mathrm{~h}$ under nitrogen atmosphere. Dry methanol $(30 \mathrm{~mL})$ was added to the solution. The resulting precipitate was filtered, rinsed with methanol, and dried.

\section{$N, N$-Dimethyl-[1,1'-binaphthalen]-2-amine (2)}

The compound was purified as a pale yellow solid by column chromatography using as eluent a solvent gradient of pentane/ ethyl acetate $(100: 0 \rightarrow 90: 10)$. Mp: $193-195{ }^{\circ} \mathrm{C}$. Yield: $47 \%$ (0.17 mmol, $52 \mathrm{mg}) .{ }^{1} \mathrm{H}$ NMR (400 MHz, $\left.\mathrm{CDCl}_{3}\right) \delta: 7.92\left(\mathrm{t},{ }^{1} \mathrm{~J}=\right.$ $8.0 \mathrm{~Hz}, 3 \mathrm{H}) ; 7.82\left(\mathrm{~d},{ }^{1} J=8.0 \mathrm{~Hz}, 1 \mathrm{H}\right) ; 7.61(\mathrm{~m}, 1 \mathrm{H}) ; 7.50\left(\mathrm{~d},{ }^{1} J=\right.$ $8.0 \mathrm{~Hz}, 1 \mathrm{H}) ; 7.48-7.44(\mathrm{~m}, 2 \mathrm{H}) ; 7.37$ (d, $\left.{ }^{1} J=8.0 \mathrm{~Hz}, 1 \mathrm{H}\right) ; 7.31-$ 7.25 (m, 2H); 7.18-7.14 (m, 1H); 7.09 (d, $\left.{ }^{1} J=8.5 \mathrm{~Hz}, 1 \mathrm{H}\right) ; 2.51$ (s, $6 \mathrm{H}) .{ }^{13} \mathrm{C}$ NMR $\left(100 \mathrm{MHz}, \mathrm{CDCl}_{3}\right) \delta=149.9\left(\mathrm{C}_{\mathrm{q}}, \mathrm{C}_{\mathrm{Ar}}-\mathrm{N}\right) ; 137.2$ $\left(\mathrm{C}_{\mathrm{q}}\right)$; $134.4\left(\mathrm{C}_{\mathrm{q}}\right) ; 133.9\left(\mathrm{C}_{\mathrm{q}}\right) ; 133.2\left(\mathrm{C}_{\mathrm{q}}\right) ; 129.7\left(\mathrm{C}_{\mathrm{q}}\right) ; 129.1\left(\mathrm{C}_{\mathrm{Ar}}-\mathrm{H}\right)$; $128.9\left(\mathrm{C}_{\mathrm{Ar}}-\mathrm{H}\right) ; 128.3\left(\mathrm{C}_{\mathrm{Ar}}-\mathrm{H}\right) ; 127.8\left(\mathrm{C}_{\mathrm{q}}\right), 127.8\left(\mathrm{C}_{\mathrm{Ar}}-\mathrm{H}\right) ; 127.6$ $\left(\mathrm{C}_{\mathrm{Ar}}-\mathrm{H}\right)$; $126.7\left(\mathrm{C}_{\mathrm{Ar}}-\mathrm{H}\right) ; 126.1\left(\mathrm{C}_{\mathrm{Ar}}-\mathrm{H}\right) ; 125.9\left(\mathrm{C}_{\mathrm{Ar}^{-}}-\mathrm{H}\right) ; 125.8\left(\mathrm{C}_{\mathrm{Ar}^{-}}\right.$ $\mathrm{H}) ; 125.8\left(2 \times \mathrm{C}_{\mathrm{Ar}}-\mathrm{H}\right) ; 123.7\left(\mathrm{C}_{\mathrm{Ar}}-\mathrm{H}\right) ; 119.8\left(\mathrm{C}_{\mathrm{Ar}}-\mathrm{H}\right) ; 44.0(2 \times$ $\mathrm{CH}_{3}$ ). HRMS (ESI-TOF) $\mathrm{m} / z[\mathrm{M}+\mathrm{Na}]^{+}$calcd for $\mathrm{C}_{22} \mathrm{H}_{19} \mathrm{NNa}$ : 320.1410; found: 320.1424 .

\section{Perylene-1-amine (4)}

The product was purified as a yellow oily solid by semipreparative TLC using as eluent pentane/ethyl acetate (90:10). In this specific case, a second consecutive semipreparative TLC was made. The product decomposes when it is exposed to air. Isolated yield: $14 \%$ (4 mg). ${ }^{1} \mathrm{H}$, COSY, HMBC and HSQC-DEPT NMR spectra are showed in ESI. $\dagger{ }^{1} \mathrm{H}$ NMR $(400 \mathrm{MHz}$, $\left.\left(\mathrm{CD}_{3}\right)_{2} \mathrm{CO}\right) \delta=7.97\left(\mathrm{~d},{ }^{1} J=7.6 \mathrm{~Hz}, 1 \mathrm{H}\right) ; 7.73-7.69(\mathrm{~m}, 2 \mathrm{H}) ; 7.23$ $\left(\mathrm{d},{ }^{1} J=7.7,1 \mathrm{H}\right) ; 7.17-7.10(\mathrm{~m}, 3 \mathrm{H}) ; 7.06-6.99(\mathrm{~m}, 2 \mathrm{H}) ; 6.81\left(\mathrm{t},{ }^{1} J\right.$ $=7.6 \mathrm{~Hz}, 1 \mathrm{H}) ; 6.72\left(\mathrm{~d},{ }^{1} \mathrm{~J}=8.8 \mathrm{~Hz}, 1 \mathrm{H}\right) ; 5.58\left(\mathrm{~s}, 2 \mathrm{H}, \mathrm{NH}_{2}\right) .{ }^{13} \mathrm{C}$ NMR $\left(100 \mathrm{MHz},\left(\mathrm{CD}_{3}\right)_{2} \mathrm{CO}\right) \delta=145.6\left(\mathrm{C}_{\mathrm{q}}, \mathrm{C}-\mathrm{N}\right) ; 134.6\left(\mathrm{C}_{\mathrm{q}}\right) ; 132.3$ $\left(\mathrm{C}_{\mathrm{q}}\right) ; 131.6\left(\mathrm{C}_{\mathrm{q}}\right) ; 130.5\left(\mathrm{C}_{\mathrm{q}}\right) ; 129.7\left(\mathrm{C}_{\mathrm{q}}\right) ; 129.1\left(\mathrm{C}_{\mathrm{q}}\right) ; 128.9\left(\mathrm{C}_{\mathrm{Ar}}-\mathrm{H}\right)$; $128.2\left(\mathrm{C}_{\mathrm{Ar}}-\mathrm{H}\right) ; 127.9\left(\mathrm{C}_{\mathrm{q}}\right) ; 126.9\left(\mathrm{C}_{\mathrm{Ar}}-\mathrm{H}\right) ; 126.7\left(2 \mathrm{C}, \mathrm{C}_{\mathrm{Ar}}-\mathrm{H}\right) ; 124.8$
$\left(\mathrm{C}_{\mathrm{Ar}}-\mathrm{H}\right) ; 122.9\left(\mathrm{C}_{\mathrm{Ar}}-\mathrm{H}\right) ; 122.2\left(\mathrm{C}_{\mathrm{Ar}}-\mathrm{H}\right) ; 121.7\left(\mathrm{C}_{\mathrm{Ar}^{-}}-\mathrm{H}\right) ; 121.5\left(\mathrm{C}_{\mathrm{Ar}^{-}}\right.$ $\mathrm{H}) ; 118.9\left(\mathrm{C}_{\mathrm{Ar}}-\mathrm{H}\right) ; 109.7\left(\mathrm{C}_{\mathrm{q}}\right) .{ }^{1} \mathrm{H}-{ }^{1} \mathrm{H}$ COSY NMR $\left(\left(\mathrm{CD}_{3}\right)_{2} \mathrm{CO}\right): \delta_{\mathrm{H}} /$ $\delta_{\mathrm{H}} 7.97 / 7.01 ; 7.71 / 6.81 ; 7.69 / 7.04 ; 7.23 / 7.04 ; 7.16 / 6.81 ; 7.11 / 6.72$; 7.13/7.01. ${ }^{1} \mathrm{H}-{ }^{13} \mathrm{C}$ HSQC NMR $\left(\left(\mathrm{CD}_{3}\right)_{2} \mathrm{CO}\right): \delta_{\mathrm{H}} / \delta_{\mathrm{C}} 7.97 / 121.5$; $7.71 / 121.7 ; 7.69 / 118.9 ; 7.23 / 126.7 ; 7.16 / 128.2 ; 7.13 / 124.8 ; 7.11 /$ 128.9; 7.04/126.7; 7.01/126.9; 6.81/122.9; 6.72/122.2. ${ }^{1} \mathrm{H}-{ }^{13} \mathrm{C}$ HMBC NMR $\left(\left(\mathrm{CD}_{3}\right)_{2} \mathrm{CO}\right): \delta_{\mathrm{H}} / \delta_{\mathrm{C}} 7.97 / 109.7 ; 7.97 / 124.8 ; 7.97 /$ $129.7 ; 7.71 / 128.2 ; 7.71 / 130.5 ; 7.71 / 131.6 ; 7.69 / 126.7 ; 7.69 /$ $129.1 ; 7.69 / 129.7 ; 7.23 / 118.9 ; 7.23 / 124.8 ; 7.23 / 129.7 ; 7.16 /$ $121.7 ; 7.16 / 128.9 ; 7.16 / 130.5 ; 7.13 / 121.5 ; 7.13 / 126.7 ; 7.13 /$ $129.7 ; 7.11 / 128.2 ; 7.11 / 130.5 ; 7.11 / 145.6 ; 7.04 / 131.6 ; 7.04 /$ $134.6 ; 7.01 / 132.3 ; 7.01 / 134.6 ; 6.81 / 127.9 ; 6.81 / 129.1 ; 6.72 /$ 109.7; 6.72/127.9; 5.58/109.7; 5.58/122.2. MS (EI): $\mathrm{m} / \mathrm{z} 267$ (100.0\%), 133 (36.0\%), 118 (19\%).

\section{$N, N$-Dimethylperylene-1-amine (5)}

The compound was purified as an orange oily solid by semipreparative TLC using as eluent a solvent gradient of pentane/ ethyl acetate (100:0 $\rightarrow 90: 10)$. Isolated yield: 50\% (15 mg). ${ }^{1} \mathrm{H},{ }^{13} \mathrm{C}$, COSY, HMBC and HSQC-DEPT NMR spectra are showed in ESI. $\dagger^{1} \mathrm{H}$ NMR (400 MHz, $\left.\left(\mathrm{CD}_{3}\right)_{2} \mathrm{CO}\right) \delta: 9.21\left(\mathrm{dd},{ }^{1} J=\right.$ $\left.7.8,{ }^{2} J=1.0 \mathrm{~Hz}, 1 \mathrm{H}\right) ; 8.21\left(\mathrm{dd},{ }^{1} J=7.5,{ }^{2} J=1.1 \mathrm{~Hz}, 2 \mathrm{H}\right) ; 7.73-$ $7.64(\mathrm{~m}, 4 \mathrm{H}) ; 7.54-7.46(\mathrm{~m}, 3 \mathrm{H}) ; 7.38$ (t, $\left.{ }^{1} J=7.8 \mathrm{~Hz}, 1 \mathrm{H}\right) ; 2.85$ (s, $6 \mathrm{H}) .{ }^{13} \mathrm{C}$ NMR (100 MHz, $\left.\left(\mathrm{CD}_{3}\right)_{2} \mathrm{CO}\right) \delta: 151.0\left(\mathrm{C}_{\mathrm{q}}, \mathrm{C}-\mathrm{N}\right) ; 135.6$ $\left(\mathrm{C}_{\mathrm{q}}\right) ; 132.5\left(\mathrm{C}_{\mathrm{q}}\right) ; 132.4\left(\mathrm{C}_{\mathrm{q}}\right) ; 131.9\left(\mathrm{C}_{\mathrm{q}}\right) ; 131.6\left(\mathrm{C}_{\mathrm{q}}\right) ; 131.6\left(\mathrm{C}_{\mathrm{q}}\right)$; $130.8\left(\mathrm{C}_{\mathrm{q}}\right) ; 129.5\left(\mathrm{C}_{\mathrm{Ar}}-\mathrm{H}\right) ; 128.5\left(\mathrm{C}_{\mathrm{Ar}}-\mathrm{H}\right) ; 128.2\left(\mathrm{C}_{\mathrm{Ar}}-\mathrm{H}\right) ; 127.5$ $\left(\mathrm{C}_{\mathrm{Ar}}-\mathrm{H}\right) ; 127.1\left(\mathrm{C}_{\mathrm{Ar}}-\mathrm{H}\right) ; 127.0\left(\mathrm{C}_{\mathrm{Ar}}-\mathrm{H}\right) ; 125.2\left(\mathrm{C}_{\mathrm{Ar}}-\mathrm{H}\right) ; 124.5\left(\mathrm{C}_{\mathrm{Ar}^{-}}\right.$ $\mathrm{H}) ; 122.1\left(\mathrm{C}_{\mathrm{Ar}}-\mathrm{H}\right) ; 121.5\left(\mathrm{C}_{\mathrm{Ar}}-\mathrm{H}\right) ; 120.1\left(\mathrm{C}_{\mathrm{Ar}}-\mathrm{H}\right) ; 119.6\left(\mathrm{C}_{\mathrm{q}}\right) ; 43.4$ (2C, $\underline{\mathrm{CH}}_{3}$ ). HRMS (ESI-TOF) $\mathrm{m} / z[\mathrm{M}+\mathrm{Na}]^{+}$calcd for $\mathrm{C}_{22} \mathrm{H}_{17} \mathrm{NNa}$ : 318.1253; found: 318.1261 .

\section{Perylene (7)}

The product was purified as a pale yellow solid by semipreparative TLC using as eluent pentane/ethyl acetate $(90: 10) .{ }^{1} \mathrm{H}$ and ${ }^{13} \mathrm{C}$ NMR spectra are showed in ESI. $\dagger^{1} \mathrm{H}$ NMR (400 MHz, $\left.\mathrm{CDCl}_{3}\right) \delta$ : $8.19\left(\mathrm{~d},{ }^{1} \mathrm{~J}=7.8 \mathrm{~Hz}, 4 \mathrm{H}\right) ; 7.68\left(\mathrm{~d},{ }^{1} J=8.0 \mathrm{~Hz}, 4 \mathrm{H}\right) ; 7.48\left(\mathrm{t},{ }^{1} J=\right.$ $7.7 \mathrm{~Hz}, 4 \mathrm{H}) .{ }^{13} \mathrm{C} \mathrm{NMR}\left(100 \mathrm{MHz}, \mathrm{CDCl}_{3}\right) \delta: 134.9\left(2 \times \mathrm{C}_{\mathrm{q}}\right) ; 131.4(2$ $\left.\times \mathrm{C}_{\mathrm{q}}\right) ; 129.0\left(4 \times \mathrm{C}_{\mathrm{q}}\right) ; 128.0\left(4 \times \mathrm{C}_{\mathrm{Ar}}-\mathrm{H}\right) ; 126.7\left(4 \times \mathrm{C}_{\mathrm{Ar}}-\mathrm{H}\right) ; 120.4$ $\left(4 \times \mathrm{C}_{\mathrm{Ar}}-\mathrm{H}\right)$. MS (EI): $m / z 252$ (100\%), 125 (18\%), 113 (7\%).

\section{Terrylene (26) ${ }^{16 a}$}

After reaction the crude was extracted in a Soxhlet apparatus, using solvents in increasing polarity starting from ethyl acetate $(100 \mathrm{~mL}$, refluxing for $24 \mathrm{~h}$ ) and then toluene (100 mL, refluxing for $24 \mathrm{~h}$ ). The product $\mathbf{2 6}$ was isolated as a dark solid. Isolated yield: $38 \%$ (29 $\mathrm{mg}$ ). UV-visible spectrum is showed in ESI. $\dagger$ UV-vis: $\lambda_{\max }$ in dichloromethane/nm: 550.4, 508.9, 476.1. Elemental analysis: calc. for $\mathrm{C}_{30} \mathrm{H}_{16}$ : C 95.7\%, H 4.28\%; found: C 95.82\%, H 4.18\%.

\section{Computational procedure}

All the calculations were performed with the Gaussian09 program. ${ }^{34}$ Based on previous results, ${ }^{45}$ the B3PW91 DFT functional $^{46}$ and the $6-31+\mathrm{G}(\mathrm{p})$ basis set were selected. Calculations were performed with full geometry optimization including in all cases the effect of the solvent through the Tomasi's polarized 
continuum model (IEFPCM) ${ }^{36 a}$ as implemented in the Gaussian package. After refinement, the characterization of stationary points was done by Hessian matrix calculations, with all positive eigenvalues for a minimum and only one negative eigenvalue for the TSs. The $x y z$ coordinates of all the obtained geometries are included in the ESI, $\dagger$ together with the SCF energy, in the case of TSs, the value of the negative frequency is also included.

\section{Conflicts of interest}

There are no conflicts to declare.

\section{Acknowledgements}

This work was partly supported by the Consejo Nacional de Investigaciones Científicas y Técnicas (CONICET), Secretaría de Ciencia y Tecnología, Universidad Nacional de Córdoba (SECyT), and the Agencia Nacional de Promoción Científica y Técnica (ANPCyT). P. C. S. gratefully acknowledges a fellowship from CONICET.

\section{References}

1 (a) Molecular Devices for Solar Energy Conversion and Storage, ed. H. Tian, G. Boschloo and A. Hagfeldt, Springer Nature, Singapore, 2018; (b) 2D Materials for Photonic and Optoelectronic Applications, ed. Q. Bao and H. Y. Hoh, Woodhead Publishing, Elsevier, Duxford, 2020; (c) V. Balzani, P. Ceroni and A. Juris, Photochemistry and Photophysics. Concepts, Research, Applications, Wiley-VCH Verlag GmbH \& Co. KGaA, Weinheim, 2014.

2 (a) J. A. Mikroyannidis, M. M. Stylianakis, M. S. Roy, P. Suresh and G. D. Sharma, Synthesis, photophysics of two new perylene bisimides and their photovoltaic performances in quasi solid state dye sensitized solar cells, J. Power Sources, 2009, 194, 1171-1179; (b) J. T. Markiewicz and F. Wudl, Perylene, Oligorylenes and Aza-Analogs, ACS Appl. Mater. Interfaces, 2015, 7, 28063-28084; (c) E. Kozma, W. Mróz, F. Villafiorita-Monteleone, F. Galeotti, A. Andicsová-Eckstein, M. Catellania and C. Botta, Perylene diimide derivatives as red and deep red-emitters for fully solution processable OLEDs, RSC Adv., 2016, 6, 6117561179; (d) É. Torres, R. Bogel-Lukasik, M. N. BerberanSantos, S. Höfle, A. Colsmannd and M. J. Brites, N,N'Diaryl-perylene-3,9-diamine derivatives: synthesis, characterization and electroluminescence properties, $R S C$ $A d v$. 2016, 6, 107180-107188; (e) R. K. Gupta and A. A. Sudhakar, Perylene-Based Liquid Crystals as Materials for Organic Electronics Applications, Langmuir, 2019, 35, 2455-2479.

3 (a) R. K. Dubey, D. Inan, S. Sengupta, E. J. R. Sudhölter, F. C. Grozema and W. F. Jager, Tunable and highly efficient light-harvesting antenna systems based on 1,7perylene-3,4,9,10-tetracarboxylic acid derivatives, Chem. Sci., 2016, 7, 3517-3533; (b) C. Huang, S. Barlow and S. R. Marder, Perylene-3,4,9,10-tetracarboxylic Acid
Diimides: Synthesis, Physical Properties, and Use in Organic Electronics, J. Org. Chem., 2011, 76, 2386-2407.

4 (a) M. Sun, K. Müllen and M. Yin, Water-soluble perylenediimides: design concepts and biological applications, Chem. Soc. Rev., 2016, 45, 1513-1528; (b) A. Venkateswararao, S.-W. Liu and K.-T. Wong, Organic polymeric and small molecular electron acceptors for organic solar cells, Mater. Sci. Eng., R, 2018, 124, 1-57; (c) F. Feng, W. Jiang and Z. Wang, Synthesis and Application of Rylene Imide Dyes as Organic Semiconducting Materials, Chem.-Asian J., 2018, 13, 20-30; (d) G. Zhang, J. Zhao, P. C. Y. Chow, K. Jiang, J. Zhang, Z. Zhu, J. Zhang, F. Huang and H. Yan, Nonfullerene Acceptor Molecules for Bulk Heterojunction Organic Solar Cells, Chem. Rev., 2018, 118, 3447-3508.

5 (a) B. A. Jones, M. J. Ahrens, M. Yoon, A. Facchetti, T. J. Marks and M. R. Wasielewski, High-Mobility Air-Stable n-Type Semiconductors with Processing Versatility: Dicyanoperylene-3,4:9,10-bis(dicarboximides), Angew. Chem., Int. Ed., 2004, 43, 6363-6366; (b) M. Gsanger, J. H. Oh, M. Konemann, H. W. Hoffken, A.-M. Krause, Z. Bao and F. Wurthner, A Crystal-Engineered HydrogenBonded Octachloroperylene Diimide with a Twisted Core: An n-Channel Organic Semiconductor, Angew. Chem., Int. Ed., 2010, 49, 740-743; (c) L. Wang, X. Zhang, G. Dai, W. Deng, J. Jie and X. Zhang, High-mobility air-stable ntype field-effect transistors based on large-area solutionprocessed organic single-crystal arrays, Nano Res., 2018, 11, 882-891; (d) L. Zonga, Y. Gonga, Y. Yua, Y. Xiea, X. Guohua, Q. Peng, Q. Li and Z. Li, New perylene diimide derivatives: stable red emission, adjustable property from ACQ to AIE, and good device performance with an EQE value of 4.93\%, Sci. Bull., 2018, 63, 108-116.

6 (a) L. Schmidt-Mende, A. Fechtenkotter, K. Müllen, E. Moons, R. H. Friend and J. D. Mackenzie, Self-organized discotic liquid crystals for high-efficiency organic photovoltaics, Science, 2001, 293, 1119-1122; (b) C. Li and H. Wonneberger, Perylene Imides for Organic Photovoltaics: Yesterday, Today, and Tomorrow, Adv. Mater., 2012, 24, 613-636; (c) E. Kozma and M. Catellani, Perylene diimides based materials for organic solar cells, Dyes Pigm., 2013, 98, 160-179; (d) S. Kumar, D. Panigrahi and A. Dhar, Role of organic interfacial modifiers in inverted polymers solar cells: an in-depth analysis of perylene vs. fullerene organic modifiers, Appl. Surf. Sci., 2018, 435, 855-862; (e) C. Yan, S. Barlow, Z. Wang, H. Yan, A. K.-Y. Jen, S. R. Marder and X. Zhan, Non-fullerene acceptors for organic solar cells, Nat. Rev. Mater., 2018, 3, 18003.

7 M. Pärs, K. Gräf, P. Bauer, M. Thelakkat and J. Köhler, Optical gating of perylene bisimide fluorescence using dithienylcyclopentene photochromic switches, Appl. Phys. Lett., 2013, 103, 221115.

8 (a) H. Wang, L. Chen, Z. Zhao and Y. Xiao, Aryl-bisalkynyl bridged perylene diimides dimers: efficient synthesis, properties and improved electron mobilities, Dyes Pigm., 2017, 144, 184-189; (b) X. Chena, Y.-N. Wanga, 
R.-X. Ronga, C.-M. Zhaoa, X.-L. Lia and K.-R. Wanga, Synthesis, thermo-responsive behavior of cyclodextrin modified bi-perylene monoimide derivative, Dyes Pigm., 2019, 160, 779-786.

9 (a) F. Ilhan, D. S. Tyson, D. J. Stasko, K. Kirschbaum and M. A. Meador, Twisted, Z-Shaped Perylene Bisimide, J. Am. Chem. Soc., 2006, 128, 702-703; (b) B. B. Rao, J.-R. Wei and C.-H. Lin, New Synthetic Routes to Z-Shape Functionalized Perylenes, Org. Lett., 2012, 14, 3640-3643.

10 (a) H. Langhals, Cyclic carboxylic imide structures as structure elements of high stability. Novel developments in perylene dye chemistry, Heterocycles, 1995, 40, 477-500; (b) C. S. Sample, E. Goto, N. V. Handa, Z. A. Page, Y. Luo and C. J. Hawker, Modular synthesis of asymmetric rylene derivatives, J. Mater. Chem. C, 2017, 5, 1052-1056; (c) T. Sakamoto and C. Pac, A "green" route to perylene dyes: direct coupling reactions of 1,8-naphthalimide and related compounds under mild conditions using a "new" base complex reagent, t-BuOK/DBN, J. Org. Chem., 2001, 66, 9498.

11 G. Dyker, Transition metal catalyzed annulation reactions. Part 3. Palladium-catalyzed annulation reactions of 1,8diiodonaphthalene, J. Org. Chem., 1993, 58, 234-238.

12 (a) H. Langhals and S. Grundner, Fluoreszenzfarbstoffe mit Fünfring-Carbonsäureimid-Strukturen, Chem. Ber., 1986, 119, 2373-2376; (b) J. T. M. V. Dijk, A. Hartwijk, A. C. Bleeker, J. Lugtenburg and J. Cornelisse, Gram Scale Synthesis of Benzo[ghi]perylene and Coronene, J. Org. Chem., 1996, 61, 1136-1139.

13 (a) A. Homer, XCVI.-The Friedel-Crafts' reaction applied to naphthalene. The action of di-, tri-, and tetra-alkyl halides. Preparation of $\alpha \beta \alpha^{\prime} \beta^{\prime}$-dinaphthanthracene, J. Chem. Soc., 1910, 97, 1141-1154; (b) R. Scholl, C. Seer and R. Weitzenböck, Perylen, ein hoch kondensierter aromatischer Kohlenwasserstoff $\mathrm{C}_{20} \mathrm{H}_{12}$, Ber. Dtsch. Chem. Ges., 1910, 43, 2202-2209; (c) R. Weitzenböck and C. Seer, Zur Kenntnis des Perylens und seiner Derivate. (2. Mitteilung), Ber. Dtsch. Chem. Ges., 1913, 43, 1994-2000; (d) M. Rickhaus, A. P. Belanger, H. A. Wegner and L. T. Scott, An Oxidation Induced by Potassium Metal. Studies on the Anionic Cyclodehydrogenation of 1,1'-Binaphthyl to Perylene, J. Org. Chem., 2010, 21, 7358-7365; (e) D. T. Gryko, J. Piechowska and M. Gałęzowski, Strongly Emitting Fluorophores Based on 1-Azaperylene Scaffold, J. Org. Chem., 2010, 75, 1297-1300; ( $f$ ) P. Schlichting, U. Rohr and K. Müllen, Easy synthesis of liquid crystalline perylene derivatives, J. Mater. Chem., 1998, 8, 2651-2655.

14 M. Grzybowski, B. Sadowski, H. Butenschön and D. T. Gryko, Synthetic Applications of Oxidative Aromatic Coupling-From Biphenols to Nanographenes, Angew. Chem., Int. Ed., 2020, 59, 2998-3027.

15 F. A. Vingiello and L. Ojakaar, New polycyclic aromatic hydrocarbons with seven fused rings, Tetrahedron, 1966, 22, 847-860.

16 (a) Y. Avlasevich, C. Kohl and K. Müllen, Facile synthesis of terrylene and its isomer benzoindenoperylene, J. Mater. Chem., 2006, 16, 1053-1057; (b) E. Buchta and J. Bösche,
Polycyclische Verbindungen, XII. Ter-a-naphthyl und terrylen, Liebigs Ann. Chem., 1962, 660, 33-40.

17 M. Wehmeier, M. Wagner and K. Müllen, Novel Perylene Chromophores Obtained by a Facile Oxidative Cyclodehydrogenation Route, Chem.-Eur. J., 2001, 7, 21972205.

18 M. Grzybowski, K. Skonieczny, H. Butenschön and D. T. Gryko, Comparison of oxidative aromatic coupling and the Scholl reaction, Angew. Chem., Int. Ed., 2013, 52, 9900-9930.

19 S. Nagarajan, C. Barthes, N. K. Girdhar, T. T. Dang and A. Gourdon, Methylterrylene isomers, Tetrahedron, 2012, 68, 9371-9375.

20 (a) E. Clar, W. Kelly, D. G. Stewart and J. W. Wright, Benzo[a] perylene and some of its derivatives, J. Chem. Soc., 1956, 2652-2656; (b) I. Agranat, Y. N. Oded, T. Mala'bi, S. Pogodin and S. Cohen, The linkage between reversible Friedel-Crafts acyl rearrangements and the Scholl reaction, Struct. Chem., 2019, 30, 1579-1611.

21 H. Z. Lecher, M. Scalera and W. S. Forster, US Pat., 2416931, Mar. 4, 1947, C. A., 1947, 41, 5151.

22 T. Horibe, S. Ohmura and K. Ishihara, Structure and Reactivity of Aromatic Radical Cations Generated by $\mathrm{FeCl}_{3}$, J. Am. Chem. Soc., 2019, 141, 1877-1881.

23 L. Zhai, R. Shukla, S. H. Wadumethrige and R. Rathore, Probing the Arenium-Ion (Proton Transfer) versus the Cation-Radical (Electron Transfer) Mechanism of Scholl Reaction Using DDQ as Oxidant, J. Org. Chem., 2010, 75, 4748-4760.

24 A. A. O. Sarhanw and C. Bolm, Iron(III) chloride in oxidative C-C coupling reactions, Chem. Soc. Rev., 2009, 38, 27302744 .

25 (a) B. T. King, J. Kroulík, C. R. Robertson, P. Rempala, C. L. Hilton, J. D. Korinek and L. M. Gortari, Controlling the Scholl Reaction, J. Org. Chem., 2007, 72, 2279-2288; (b) S. Nobusue, K. Fujita and Y. Tobe, Skeletal Rearrangement of Twisted Polycyclic Aromatic Hydrocarbons under Scholl Reaction Conditions, Org. Lett., 2017, 19, 3227-3230; (c) J. Liu, A. Narita, S. Osella, W. Zhang, D. Schollmeyer, D. Beljonne, X. Feng and K. Müllen, Unexpected Scholl Reaction of 6,7,13,14-Tetraarylbenzo[k]tetraphene: Selective Formation of Five-Membered Rings in Polycyclic Aromatic Hydrocarbons, J. Am. Chem. Soc., 2016, 138, 2602-2608.

26 (a) K. Ding, Q. Xu, Y. Wang, J. Liu, Z. Yu, B. Du, Y. Wu, H. Koshima and T. Matsuura, Novel two-phase oxidative cross-coupling of the two-component molecular crystal of 2-naphthol and 2-naphthylamine, Chem. Commun., 1997, 693-694; (b) K. Ding, Y. Wang, L. Zhang, Y. Wu and T. Matsuura, A novel two-phase oxidative coupling of 2naphthols suspended in aqueous $\mathrm{Fe}^{3+}$ solutions, Tetrahedron, 1996, 52, 1005-1010.

27 A. Zinke and R. Dengg, Eine Synthese des Perylens über das 1,12-Dioxyperylen, Monatsh. Chem., 1922, 43, 125-128.

28 (a) A. B. Pierini, M. T. Baumgartner and R. A. Rossi, Regiochemistry of the coupling of aryl radicals with nucleophiles derived from the naphthyl system. Experimental and theoretical studies, J. Org. Chem., 1991, 
56, 580-586; (b) L. B. Jimenez, N. V. Torres, J. L. Borioni and A. B. Pierini, Synthesis of triaryls: hydroxy and amine dinaphthyl and diphenanthryl aryls by one-pot electrontransfer nucleophilic substitution reactions, Tetrahedron, 2014, 70, 3614-3620; (c) A. B. Pierini, M. T. Baumgartner and R. A. Rossi, Photostimulated reactions of haloarenes with 2-naphtylamide ions. A facile synthesis of 1-aryl-2naphthylamines, Tetrahedron Lett., 1987, 28, 4653-4656.

29 Information about the relative $\Delta G_{\sigma}$ of formation of the arenium cation at all positions is included in the ESI. $\dagger$

$30 \mathrm{UV}$-vis and fluorescence spectra are shown in ESI. $\dagger$

31 (a) S. L. Skraba-Joiner, E. C. McLaughlin, A. Ajaz, R. Thamatam and R. P. Johnson, Scholl Cyclizations of Aryl Naphthalenes: Rearrangement Precedes Cyclization, $J$. Org. Chem., 2015, 80, 9578-9583; (b) P. Kovacic and F. W. Koch, Coupling of Naphthalene Nuclei by Lewis Acid Catalyst-Oxidant, J. Org. Chem., 1965, 30, 3176-3281.

32 R. J. Baumgarten and V. A. Curtis, in Supplement F. The Chemistry of Amino, Nitroso and Nitro Compounds and their Derivatives. Part 2., ed. S. Patai, John Wiley \& Sons Ltd., Jerusalem, 1982, p. 929.

33 O. M. Demchuk, K. Kapłon, L. Mazur, D. Strzelecka and K. M. Pietrusiewicz, Readily available catalysts for demanding Suzuki-Miyaura couplings under mild conditions, Tetrahedron, 2016, 72, 6668-6677.

34 M. J. Frisch, G. W. Trucks, H. B. Schlegel, G. E. Scuseria, M. A. Robb, J. R. Cheeseman, G. Scalmani, V. Barone, B. Mennucci, G. A. Petersson, H. Nakatsuji, M. Caricato, X. Li, H. P. Hratchian, A. F. Izmaylov, J. Bloino, G. Zheng, J. L. Sonnenberg, M. Hada, M. Ehara, K. Toyota, R. Fukuda, J. Hasegawa, M. Ishida, T. Nakajima, Y. Honda, O. Kitao, H. Nakai, T. Vreven, J. A. Montgomery Jr, J. E. Peralta, F. Ogliaro, M. Bearpark, J. J. Heyd, E. Brothers, K. N. Kudin, V. N. Staroverov, R. Kobayashi, J. Normand, K. Raghavachari, A. Rendell, J. C. Burant, S. S. Iyengar, J. Tomasi, M. Cossi, N. Rega, N. J. Millam, M. Klene, J. E. Knox, J. B. Cross, V. Bakken, C. Adamo, J. Jaramillo, R. Gomperts, R. E. Stratmann, O. Yazyev, A. J. Austin, R. Cammi, C. Pomelli, J. W. Ochterski, R. L. Martin, K. Morokuma, V. G. Zakrzewski, G. A. Voth, P. Salvador, J. J. Dannenberg, S. Dapprich, A. D. Daniels, Ö. Farkas, J. B. Foresman, J. V. Ortiz, J. Cioslowski and D. J. Fox, Gaussian 09, Revision E.01, Gaussian, Inc., Wallingford CT, 2009.

35 (a) J. P. Perdew, Electronic Structure of Solids, Akademie Verlag, Berlin, 1991; (b) K. Burke, J. P. Perdew and Y. Wang, Electronic Density Functional Theory: Recent Progress and New Directions, Plenum Press, New York, 1998.

36 (a) J. Tomasi, B. Mennucci and R. Cammi, Quantum Mechanical Continuum Solvation Models, Chem. Rev., 2005, 105, 2999-3094; (b) Since the properties of the mixture of $\mathrm{AlCl}_{3}$ and $\mathrm{NaCl}$ as solvent are not known, we carried out the calculations within these too different media, even though the results were the same, within less than $1 \mathrm{kcal} \mathrm{mol} \mathrm{m}^{-1}$ of difference in the $\Delta G$ computed in both solvents models.

37 The distribution in the formation of the $\sigma$-complex of $\mathbf{1 a}$ $\left(\mathrm{R}=\mathrm{NH}_{3}{ }^{+}\right)$and $2 \mathbf{a}\left(\mathrm{R}=\mathrm{N}\left(\mathrm{CH}_{3}\right)_{3}{ }^{+}\right)$could be considered as similar, hence the calculations on 2 a were not carried out.

38 Photochromism: Molecules and Systems, ed. H. Dürr and H. Bouas-Laurent, Elsevier Science, 2003.

39 A value of $86.1 \mathrm{kcal} \mathrm{mol}^{-1}$ was found for the $\Delta G_{\mathrm{r}}$ of the formation of the product coupling (intermediary).

40 (a) U. C. Singh and P. A. Kollman, An approach to computing electrostatic charges for molecules, J. Comput. Chem., 1984, 5, 129-145; (b) B. H. Besler, K. M. Merz Jr and P. A. Kollman, Atomic charges derived from semiempirical methods, J. Comp广ut. Chem., 1990, 11, 431-439.

41 It should be noted that this potential represents the absolute value of half of the redox reaction, a hemi-couple, whereas the experimental values are relative to a reference hemicouple where the reduction takes place. See ref. 43 .

42 References of experimental studies of compounds presented in Fig. 2, used for the calculations of oxidation potential are included in ESI, $\uparrow$ section 7, p. 28.

43 (a) A. I. Vogel, Vogel's Textbook of Practical Organic Chemistry, ed. B. S. Furnis, A. J. Hannaford, P. W. G. Smith and A. R. Tatchell, John Wiley \& Sons, Inc., New York, 5th edn, 1989; (b) E. Guillen, J. Hierrezuelo, R. Martínez-Mallorquín, J. M. López-Romero and R. Rico, Suzuki-Miyaura monocouplings of $p$-dibromobiphenyl and substituted $p$ dibromo(penta- $p$-phenylenes), Tetrahedron, 2011, 67, 25552561.

44 W. Guo, E. Faggi, R. M. Sebastian, A. Vallribera, R. Pleixats and A. Shafir, Direct Arylation of Oligonaphthalenes Using $\mathrm{PIFA} / \mathrm{BF}_{3} \cdot \mathrm{Et}_{2} \mathrm{O}$ : From Double Arylation to Larger Oligoarene Products, J. Org. Chem., 2013, 78, 8169-8175.

45 J. L. Borioni, M. Puiatti, D. M. A. Vera and A. B. Pierini, In search of the best DFT functional for dealing with organic anionic species, Phys. Chem. Chem. Phys., 2017, 19, 91899198.

46 (a) J. P. Perdew and Y. Wang, Accurate and simple analytic representation of the electron-gas correlation energy, Phys. Rev. B: Condens. Matter Mater. Phys., 1992, 45, 1324413249. Erratum: Phys. Rev. B, 2018, 98, 079904(E); (b) J. P. Perdew, J. A. Chevary, S. H. Vosko, K. A. Jackson, M. R. Pederson, D. J. Singh and C. Fiolhais, Atoms, molecules, solids, and surfaces: applications of the generalized gradient approximation for exchange and correlation, Phys. Rev. B: Condens. Matter Mater. Phys., 1992, 46, 6671-6687. Erratum: Phys. Rev. B Condes. Matter Mater. Phys., 1993, 48, 4978; (c) J. P. Perdew, K. Burke and Y. Wang, Generalized gradient approximation for the exchange-correlation hole of a many-electron system, Phys. Rev. B: Condens. Matter Mater. Phys., 1996, 54, 1653316539; (d) A. D. Becke, Density-functional thermochemistry. III. The role of exact exchange, J. Chem. Phys., 1993, 98, 5648-5652. 